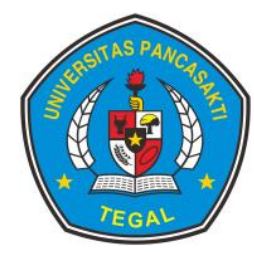

JURNAL ILMU PEMERINTAHAN:

Kajian Ilmu Pemerintahan dan Politik Daerah

Volume 6- Nomor 1, April 2021, (HIm 44-55)

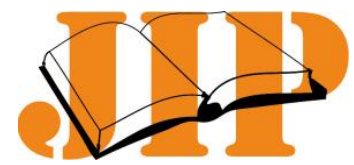

Available online at: http://governmentjournal.org/

\title{
Institutional Analysis of Independent During Pandemic Era in Sleman Regency, Special Region of Yogyakarta
}

\author{
Gerry Katon Mahendraa*; Nur Faidatib \\ ${ }^{a b}$ Universitas 'Aisyiyah Yogyakarta, Indonesia
}

\begin{tabular}{|c|c|}
\hline Information Article & $A B S T R A C T$ \\
\hline History Article & This paper intends to This study focuses on independent tourism village \\
\hline Submission : 03-02-2021 & institutions during pandemic era in Sleman Regency, Special Region of Yogyakarta. \\
\hline Revision : 08-02-2021 & The research method used in this research is qualitative research methods. This \\
\hline Accepted : 22-03-2021 & $\begin{array}{l}\text { research was conducted in } 10 \text { Independent Tourism Villages in Sleman Regency, } \\
\text { between August - December } 2020 \text {. In this study, three data collection techniques }\end{array}$ \\
\hline DOI Article: & were used, including: literature study, interviews and documentation. Of the 10 \\
\hline $\begin{array}{l}10.24905 / j i p .6 .1 .2021 .44- \\
55\end{array}$ & $\begin{array}{l}\text { to a pandemic situation. Meanwhile, the other } 5 \text { are not sufficiently well- } \\
\text { institutionalized and capable of adapting to the pandemic situation. Tourist villages } \\
\text { that are able to adapt are able to innovate in realizing quality tourism that pays } \\
\text { attention to safety and health aspects through Cleanliness, Health, Safety and } \\
\text { Environmental Sustainability (CHSE) }\end{array}$ \\
\hline
\end{tabular}

Keyword: Tourism Village, Institutional Analysis, Pandemic Era

(C) 2021 Published by Governmental Studies. Selection and/or peer-review under responsibility of JIP.

\footnotetext{
* Corresponding author

E-mail address: gerrykaton@unisayogya.ac.id
} 


\section{Jurnal Ilmu Pemerintahan: Kajian Ilmu Pemerintahan dan Politik Daerah, Vol. 6(1), April 2021 - 45}

Gerry Katon Mahendra $\mathrm{a}^{{ }^{*}}$, Nur Faidati ${ }^{\mathrm{b}}$

\section{Introduction}

With respect to urban-rural planning context, the potentials of creative industry actors, creativities, and materials are usually plentiful in the rural areas. (Maiti \& Bidinger, 2017). The tourism sector increasingly shows positive development, attracting tourists to visit tourism objects or destinations. Therefore, each country, including Indonesia, more intensively develops tourism because it has an impact on economic development and improves people's welfare. (Sumarto, Sumartono, Muluk, \& Nuh, 2020). This study focuses on independent tourism village institutions during pandemic era in Sleman Regency, Special Region of Yogyakarta. Previous research was mostly carried out on institution of village tourism in normal situation. (Utomo \& Satriawan, 2018)

However, Household welfare is determined by expected lifetime consumption and health status. As the coronavirus outbreak hinders tourism consumption and health status, welfare also declines. (Yang, Zhang, \& Chen, 2020). There are many regions in Indonesia where one of the biggest income earners is tourism, some of which are Yogyakarta. Every region in Indonesia has various natural resource potentials. The potential natural resources possessed by each region are then explored through empowerment activities. Natural resource exploration activities can be in the form of mining, agriculture, plantation, animal husbandry, to natural wealth-based tourism village management, which generally includes collaboration in natural resource management activities and the overall culture of local wisdom that is owned. And also intangible culture formed in many different form as the response of the commercialization. (Rudwiarti, Pudianti, \& Vitasurya, 2017).

tourism sector is indeed an awning industry related to many of the other sectors of the economy including hotel, restaurant, resort, travel agency, Local level activities, employment, banking, forestry, medical, travel and transportation, construction, real estate, retail, and vice versa. (Riadil, 2020)

Jogja tourism is one of the attractive destinations visited by foreign and domestic tourists after Bali. (Sugandini, Effendi, Aribowo, \& Utami, 2018). In general, a tourism village is a form of integration between attractions, accommodation and supporting facilities that are presented in a structure of community life that integrates with the prevailing procedures and traditions. (La Rocca, 2014) Meanwhile, according to another opinion, it is argued that a tourist village is a rural area that offers an overall atmosphere that reflects rural authenticity both from socio-economic life, socio-culture, customs, daily life, has a unique building architecture and spatial structure, or unique economic activities and attractive and has the potential to develop various components of tourism, such as attractions, accommodation, food and drink, and other tourism needs. (Hadiwijoyo, 2012)

The purpose of establishing a tourist village is to develop the potential of the village so that it becomes a new tourism potential which in the end can provide broad benefits. The Special Region of Yogyakarta (DIY) has been known as one of the best tourist destinations in Indonesia. It is recorded until June 2018, based on data from the Yogyakarta City Tourism Office, the number of tourists visiting the city of Yogyakarta, both foreign tourists and domestic tourists, reached 1,859,888 people.

This figure is predicted to continue to grow along with the positive image of DIY tourism. The tourist village is one of the leading tourist destinations owned by DIY and is intensively visited by tourists. This is because of community participation to develop their own infrastructure and facilities to support educational craft industry tourist attraction to be more attractive for tourists. (Vitasurya, 2016) Community-Based Ecotourism is a form of ecotourism that emphasizes the development of local communities; allowing for local residents to have great control over. (Purbasari \& Manaf, 2018). 


\section{Jurnal Ilmu Pemerintahan: Kajian Ilmu Pemerintahan dan Politik Daerah, Vol. 6 (1), April 2021 - 46}

Gerry Katon Mahendra ${ }^{a^{*}}$, Nur Faidati ${ }^{b}$

Stakeholder participation in tourism planning is crucial for destination development. The results indicate that stakeholder participation in tourism planning is important. (Nguyen, Diane, \& Newsome, 2020)

Sleman Regency is listed as one of the districts that has the largest number of tourist villages which are often tourist destinations. In 2019 the Sleman Tourism Office recorded 47 tourist villages in Sleman Regency. However, not all of them have the status of tourism villages that are ready for institutional management. In its classification, there are at least four classifications of tourist villages, starting from piloting, growing, developing, and being independent. The independent category is the highest category with a total of 10 tourist villages. Tourism Villages belonging to this category are Brayut Tourism Village, Grogol Tourism Village, Pentingsari Tourism Village, Rumah Domes Tourism Village, Kelor Tourism Village, Gamplong Tourism Village, Pulesari Tourism Village, Sukunan Tourism Village, Pancoh Tourism Village, and Blue Lagoon Tourism Village. Ideally, the Tourism Village above is able to achieve ideal conditions in an institutional context, which includes the organizational structure, the ability to carry out personnel duties in the inter-institutional and interinstitutional organizational structures.

The ideal condition for the Tourism Village institution that is owned by the Independent Tourism Village is hoped that it will be able to have an impact on its ability to adapt to pandemic conditions, so that the Independent Tourism Village will still be able to operate in all situations. In reality, the Independent Tourism Villages in Sleman Regency, which have better institutions than other tourism village categories, do not all have institutional and operational readiness to face a pandemic.

the existence of tourism awareness group in the village is no less important in the development of tourism villages because community participation in the development of tourism villages starts from the existence of tourism awareness group starting from the initiation, planning, implementation, supervision, and evaluation stages in village tourism business activities. (Arintoko, Ahmad, Gunawan, \& Supadi, 2020), However, during a pandemic, tourism becomes a difficult activity to do.

Because of that, the paper intends to analyze the institutional governance of tourism village in the independent category with the aim of obtaining an analysis of the best management model from the 10 tourist villages so that they can be referred to tourist villages in Sleman Regency and throughout Indonesia in terms of institutional management. It is hoped that the strengthening of the institutional process will be able to make the tourism village last longer and always be able to respond to the environment and market wants so that its existence can be maintained.

\section{Method}

The research method used in this research is qualitative research methods. This research was conducted in 10 Independent Tourism Villages in Sleman Regency, between August December 2020.

In this study, three data collection techniques were used, including: desk study, interview and documentation. The interview is used to gather information from the management of independent tourism villages in Sleman Regency, the Tourism Office of Sleman Regency and experts in developing tourism villages. Data analysis was carried out in three stages which included data reduction, data display and analysis, as well as drawing conclusions and verification. (Huberman, M., \& Miles, 2002)

\section{Results and Discussion}

States that the organizational level is related to the organizational structure, culture and management tools that support individuals to show their best performance. (Milen, 2006). Considering that this research was conducted in the realm of tourism, indicators that are deemed 


\section{Jurnal Ilmu Pemerintahan: Kajian Ilmu Pemerintahan dan Politik Daerah,}

Vol. 6(1), April 2021 - 47

Gerry Katon Mahendra ${ }^{a^{*}}$, Nur Faidati ${ }^{\mathrm{b}}$

suitable to measure the organizational capabilities and capacities of tourism village managers will refer to the opinion of (Damanik, J., \& Weber, 2006), namely the ability of organizations to lead and coordinate, the ability of organizations to undertake external partnerships. organizations to develop tourism products, as well as organizational capabilities to promote

A tourist village is a rural area that offers an overall atmosphere that reflects the authenticity of the village, both from socio-economic life, socio-culture, customs, daily life, has a unique building architecture and spatial structure, or unique and interesting economic activities and has the potential to develop various tourism components, such as attractions, accommodation, food and beverages, and other tourism needs. (Hadiwijoyo, 2012)

\section{Gamplong Tourism Village}

Tourism is the activity of people traveling to and living in places outside of their usual neighborhoods, often for relaxation. (Manaf, Purbasari, Damayanti, Aprilia, \& Astuti, 2018). Gamplong tourism village is a tourist village that offers tour packages for natural fiber crafts which have been legendary since the Dutch era. In the institutional management of the tourist village, institutionally forming a TEGAR association that changes management every 3 years. This tourism association was formed based on the principles of openness and overall accountability. Thanks to the persistence of the tourism association manager, they were able to produce brilliant achievements for the management of the Gamplong tourism village, namely being part of the Indonesia Sustainable Tourism Award (ISTA) of the Ministry of Tourism in mid 2018-2019.

The process of managing the Gamplong tourism village is precisely directed to be inclusive because it always involves outside parties through the coordinators. Examples of cooperation include providing houses and empty rooms for guests, which is a community task. In addition, tour guides who are in charge of accompanying tourists must also come from the community, culinary delights, and always coordinate with people who do have unique crafts so that their products can be sold in a tourist village environment. In addition, the cooperation process is also carried out with universities, especially in terms of tourism promotion.

In the process of managing a tourism village, the association committee also emphasizes that the community can be actively and sustainably involved. This is slowly growing, marked by the growing awareness of the tourism mindset in each community. The association also makes a policy in every profit from the activity, so $10 \%$ of it will be returned to the community to maintain and add assets. In addition, the association also encouraged the formation of the Gamplong tourism village forum which contained representatives from Gamplong 1 to Gamplong 5. The Village Supervisory Agency (BPD) was also presented with the Village Supervisory Agency (BPD) so that any input aspirations could be forwarded to higher institutional entities, namely the Village government. Operationally, the expected cooperation includes the following:

1) Integrative cooperation between Gamplong tourism village and Gamplong nature film studio, starting from nature studios, education, agriculture, culture, handicrafts, animal husbandry to camping ground are united into a superior tourism village that can compete with other tourist villages nationally;

2) Gamplong tourism village hopes to build a local culinary area and showroom that accommodates and displays community handicrafts and is in a location close to the Gamplong nature studio area, considering that visits to nature studios are quite high;

3) Cooperate and work together with the village government so that they can be allowed to use village land in order to build an adequate camping ground and parir area. It is felt that the cooperation between the village government, tourist villages and

Licensed under $(\mathrm{cc})$ BY-NC a Creative Commons Attribution-NonCommercial 4.o International License, 


\section{Jurnal Ilmu Pemerintahan: Kajian Ilmu Pemerintahan dan Politik Daerah, Vol. 6 (1), April 2021 - 48}

Gerry Katon Mahendra ${ }^{a^{*}}$, Nur Faidati ${ }^{b}$

nature studios in this context will further increase the interest of tourists. At this point, there are still no significant results and are still in the process of negotiation, especially regarding the status of the manager whether through association or BUMDes;

4) Increase the MoU with external parties. So far, the Mou that has been implemented is still limited from universities and tourism actors, such as Mercubuana University, UGM, and Rosin Hotel. In the future, we hope that there will be bids and submissions of MoUs from other external parties that can provide assistance

\section{Pentingsari Tourism Village}

According to North in (Arsyad Sitanala, 2010) institutions are rules created by humans to regulate and shape political, social and economic interactions. These rules consist of formal rules (for example: laws, constitutions) and informal rules (for example: social norms, conventions, customs, value systems) and the process of enforcing these rules. Taken together, these rules determine the incentive structure for society, particularly the economy. These rules were created by humans to create good order and reduce uncertainty in the exchange process.

A tourist village is a rural area that offers an overall atmosphere that reflects the authenticity of the village, both from socio-economic life, socio-culture, customs, daily life, has a unique building architecture and spatial structure, or unique and interesting economic activities and has the potential to develop various tourism components, such as attractions, accommodation, food and beverages, and other tourism needs. (Hadiwijoyo, 2012). Based on above framework, it can be known that the management of tourism village institutions is one of the important things in order to maintain the sustainability and development of tourism villages. With the existence of strong institutions (in all aspects), tourism villages will undoubtedly survive, exist, and are also expected to continue to be able to present innovative services to tourists.

On this occasion, researchers tried to present the results of research on the management of tourism villages in Sleman Regency, from an institutional point of view.

\section{Pancoh Ecowisata Village}

Pancoh Hamlet was designated as a tourist village on February 14, 2012 after the Merapi eruption disaster. The establishment of this tourist village was driven by the declining economic condition of the community due to damage to agricultural land after the eruption of Merapi. Identification of the potential and development of Dusun Pancoh as a tourist area is carried out together with social institutions that assist in the recovery of the condition of residents and their housing environment after the eruption of Merapi.

Taking into account the natural and cultural potential of Dusun Pancoh, this hamlet was developed as an ecotourism village. (Martshita, 2014) The potential that was seeded during the early days of its establishment was salak plantations, agricultural land and vegetables, as well as traditional surthong art works that can be found in almost all parts of Pancoh Hamlet.

Pancoh Hamlet as a tourism destination is part of the potential of a tourist village recorded in the mapping of potential locations for tourism villages in Sleman Regency in 2015. (Putra \& Fauzy, 2015). In its development, Pancoh Hamlet provides a variety of outbound tourism activities by utilizing the resources owned by this village. Nature tourism activities held in this hamlet include: river trails and village roaming. Educational tourism activities are carried out through the participation of tourists in plowing activities, catching fish and picking salak fruit or vegetables. Art and cultural activities are held through training in dance, gamelan, batik and bamboo weaving. Various tourist activities in the village were attended by various age groups and from various regions. 


\section{Jurnal Ilmu Pemerintahan: Kajian Ilmu Pemerintahan dan Politik Daerah, Vol. 6(1), April 2021 - 49 \\ Gerry Katon Mahendra ${ }^{a^{*}}$, Nur Faidati ${ }^{\mathrm{b}}$}

The management pattern of the Pancoh ecotourism village involves the community as tourism activities. The division of tasks between the components in it is as follows:

- Tourism Awareness Group and Pancoh Ecotourism Manager as Technical Implementers and Activity Managers

- "AKUR" Farmer Group as guide for Agricultural Education Package

- PKK group "CATERING LARIS" as a Provider of Culinary Processes and Learning Packages

- Livestock Group "GAWE RUKUN" as a guide for Bio Gas Education Package and Cattle and Goat Livestock Care

- Art groups "LARAS MADYO, TARUNO BUDOYO and TRIMO LUWUNG" as welcoming guests and art learning packages

- Youth Youth Organization "IPP PANCOH" as a tour guide

- Environmental Awareness Group "NGUDI ASRI" as the guide for the Waste Bank and Garbage Processing Education package.

The income earned by Ecotourism Village Pancoh has increased significantly since its establishment until 2019. It is recorded that the income of Pancoh Ecotourism Village in 209 has reached around 650 million.

Apart from involving the community, Pancoh ecotourism village also collaborates with many stakeholders development, including:

1. Internal Management Cooperation

a) Cooperation between managers (between individual managers consisting of RW)

b) Tourism Manager Collaboration with Community Groups

c) Cooperation between Tourism Managers and the general public

2. Collaboration with the Community (VW community, Interfaith and Culture,
Forkom, Tourism Village District, Regency, Province and all over Java)

3. Collaboration with Academics (UGM, STIPRAM, UPY, UTY, UKDW, IPB, SAMARINDA STATE POLTEK, SANATA DHARMA, STELLADUCE 2 SMA)

4. Collaboration with the Government (Provincial and Regency Tourism Offices, Cultural Services, DLH, Ministry of Tourism)

5. Cooperation with Private Parties (Villageria, Cantrik, Ijo Lumut)

6. Collaboration with NGOs (UNIDO, STORM, LPTP, INSIST)

7. Collaboration with Puskesmas Turi

Pancoh ecotourism village also has a number of achievements, namely:

1. First Winner of Tourism Village Competition at Sleman Regency Level for Developing Tourism Village Category, 2016 and 20172018 (3 consecutive years)

2. Yogyakarta Province Culinary Competition Favorite Winner, 2016

3. 3rd Place in the DIY Provincial Level Tourism Village and Village Competition, 2017

4. Year 2018 as a Nomination for ISTA (Indonesian Sustainable Tourism Awards)

5. Hope 1 Village and Tourism Village Competition at the Provincial Level of DIY, 2019

6. 1st Winner of Tourism Village Competition at Sleman Regency Level, Category, Independent. 2019

7. 2nd Place in the DIY Provincial Level Tourism Village and Village Competition, 2020 
Jurnal Ilmu Pemerintahan: Kajian Ilmu Pemerintahan dan Politik Daerah, Vol. 6 (1), April 2021 - 50

Gerry Katon Mahendra ${ }^{a^{*}}$, Nur Faidati ${ }^{\mathrm{b}}$

\section{Pulesari Tourism Village}

Wisaya Pulesari Village was developed and officially launched in 2012. Pulesari tourism village was formed on the basis of the challenges of the post-eruption situation of Mount Merapi in 2010 as well as creative ideas from the community who see the existing potentials (one of which is barking cultivation). Other tourism activities that can be done when visiting Pulesari tourism village are outbound activities, trekking and river tours.

The initiation of the development of the Pulesari Tourism Village was born from the local community so that from the beginning of the process to management it was carried out by the local community. Now Pulesari Tourism Village is able to develop and is widely known and is able to provide benefits to the local community. However, like other independent tourism villages in Sleman Regency, Pulesari tourism village also faces several problems in terms of management.

The first problem is related to limited human resources. The second problem is related to the absence of village treasury land/land as already available in other tourist villages. The third problem is the existence of a conflict of interest between the tourism village manager and the village party related to income from tourism. For the first problem, limited human resources were overcome by upgrading soft skills and hard skills and maximizing the quantity of available human resources. This is done so that operations can continue to run well.

As for the second problem, related to the absence of land, the manager independently and also assisted by various supporting parties is ultimately able to provide/buy land to support tourism activities. The third problem is still a classic problem that is generally felt by each tourism village, especially tourism villages whose management process is still separate from the village / BUMDes government.

Furthermore, related to the post-pandemic plan, the management of the Pulesari Tourism Village planned several basic things. First, related to the readiness of residents related to the implementation of SOPs for tourism services. Second, the manager is waiting for a regulation (Governor Regulation) to support the operational activities of the tourist village. Third, the preparation of infrastructure during the pandemic period which will be carried out in three stages, namely the sink installation program; spraying disinfectants and other things that support it.

\section{Kelor Tourism Village}

Kelor tourism village was formed in mid 2005. Initially, this tourism village was managed by community leaders (village elders) and gradually transferred to the young generation in the village within the scope of tourism village management groups that were not affiliated with BUMDes. The organizational structure refers to the institutional organizational structure consisting of advisors, chairpersons, treasurers, and sections.

In connection with its progress, at first this tourist village was not well known by the wider community. Finally, when it began to be managed by young people who were considered to be more active and creative in promoting the tourism village, slowly but surely Kelor Tourism Village was able to attract many visitors from all over cities.

The tourism profile in Kelor Tourism Village is generally mountainous nature tourism with outbound facilities and a joglo house as its main support which stands on the land of the local village treasury. In addition, Kelor Tourism Village also has several traditional arts, namely: jathilan (horse lumping), gamelan, kethoprak, Yogyakarta traditional dance and sholawatan klenthingan. Cultural traditions that are still well preserved include the tradition of the life cycle, namely birth, circumcision, mantenan, mitoni, brokohan selapanan. The Javanese traditional traditions of Suran, Saparan, Selikuran and Ruwahan still exist in society today.

Along with this pandemic period, the management of Kelor Tourism Village has taken 


\section{Jurnal Ilmu Pemerintahan: Kajian Ilmu Pemerintahan dan Politik Daerah, Vol. 6(1), April 2021 - 51 \\ Gerry Katon Mahendra ${ }^{a^{*}}$, Nur Faidati ${ }^{\mathrm{b}}$}

the initiative to strengthen services based on health protocol SOPs in order to minimize the spread of the virus in tourist attractions.

\section{Brayut Village Tourism}

Brayut Tourism Village, located in Brayut Hamlet, Pendowoharjo Village, which is also the first tourism village in Sleman Regency and is an example for other potential tourism villages. Brayut Tourism Village as an agriculture-based tourism village offers attractive tour packages and is close to nature.

Agricultural land in Brayut is focused on the development of rice, corn, soybean, peanuts, long beans and chilies. Tourists who stay at Brayut Tourism Village can enjoy a variety of delicious culinary or traditional village food, such as legondo, klepon, or other traditional Javanese food. The social activities that have been developed include musical instruments, batik, and traditional dance, which are supported by the existence of a musical studio, a batik studio, and a dance studio and its teachers.

In its management, the head of the Brayut Tourism Village management is responsible for the slightest problems faced by visiting tourists. The management of a tourism village is emphasized on empowering the local community so that the management of a tourist village and its activities can have multi-effects for the community.

\section{Grogol Village Tourism}

The general profile of Grogol Tourism Village is a cultural tourism village. The tourist village has a cultural center, the Friday Pahing market, and the Sunan Kalijaga patilasan. In addition, Grogol Tourism Village also continues to promote natural tourism as part of its leading destinations. Grogol Tourism Village was formed in 2014 and already has a management, even though it is only social and voluntary. The advantage of this structure is that the relationship between members is relatively close and compact, but the drawback is the unclear jobdesk and professionalism among the board members.

Technically, the management and implementation process is carried out in a simple manner and uses a lot of the Whatsapp group application which consists of a group of conceptors and an implementing group. Initial ideas are processed first in the drafter group, then discussed in a technical and detailed manner in the implementing group. The technical implementation of tourism village activities in Grogol is also based on activities that are by order.

The management group in a coordinated manner will provide assistance and tour services to guests who come and do activities at the place. The personnel selection process is also based on who has free time at that time, even though previously each personnel already had the ability to be formally trained in serving visiting guests. The problems in Grogol Tourism Village are related to institutions and management related to human resources. One of these problems is reflected in the lack of management of promotion facilities that should be maximized by the manager.

\section{Dome House Tourist Village}

The tour of the Dome Houses originated from the 2006 Yogyakarta earthquake. The earthquake also had an impact on conditions in Lepen Village, which incidentally was located in a hilly area that experienced a shift in one village, so that the houses in the area collapsed. Geographically, the area is categorized as unstable soil so that after the earthquake the community was not allowed to live in the area anymore.

On this basis, the village government then provided land, namely for the relocation of community members, totaling 71 households. In addition, there are also international NGOs that come with the aim of providing assistance and dome-shaped houses. 


\section{Jurnal Ilmu Pemerintahan: Kajian Ilmu Pemerintahan dan Politik Daerah,}

Vol. 6 (1), April 2021 - 52

Gerry Katon Mahendra ${ }^{a^{*}}$, Nur Faidati ${ }^{\mathrm{b}}$

In 2008, the enthusiasm of the people who wanted to know more about the dome house grew bigger. This has contributed to the formation of the tour initiation of the Dome House in Yogyakarta. At the same time, the management has also been strengthened so that it is able to work and serve visitors optimally.

The management of the Dome House Tourism Village began with a tour management group that contained a coach, chairperson, and activity sections that continued until 2017, the management was strengthened in the form of a legally-centuries-old cooperative. Enthusiasm that is consistent and able to have a positive impact on the people of the Dome House has made the Sleman Regency Tourism Office together with the administrators to initiate the formation of the Dome House Tourism Village in 2018.

\section{Sukunan Tourist Village}

Sukunan Village initially focused on waste management. One of its main activities is waste management and the environment which offers educational programs on how to manage waste and how to manage the environment. In general, the main visitor profiles come from government agencies, schools, universities, especially those related to waste management and the environment. After becoming a tourist village, Dusun Sukunan then completed its services to include culinary, arts and lodging. Typical culinary delights include melinjo chips, jadah tempeh, tofu, and tempeh. The arts displayed include musical culture, tambourines, and jathilan groups.

Operationally, waste management in Sukunan Tourism Village is carried out by 2 methods, namely by shodaqoh garbage and garbage banks. Shodaqoh waste is done by sorting household waste into trash cans at each point, where at each point there are 3 cans each for plastics, paper and foodstuffs.

Furthermore, during the next 7-10 days the waste is brought to the warehouse for sale. The proceeds from the sale are then put into the residents' treasury. Meanwhile, for waste banks, in general, the concept is the same, namely saving waste. The community is asked to sort first, recyclable waste and then take it to the warehouse. Furthermore, there will be garbage bank officers who accept and weigh and then give rewards to people who save waste. The accumulative results owned by the manager are then sold. The sales proceeds are then cut $25 \%$ for operational activities.

Talking about the institutions, the organizations owned by the Sukunan Tourism Village, especially in their superior tourism, are based at the RW level, especially in the cleanliness and environment section. This section is in charge of managing waste banks, shodaqoh waste, and special waste management units into ready-to-use items. Whereas for the management of Sukunan Tourism Village at a more general level, its management involves components at the RW level, youth and community leaders who are willing to be the drivers of tourism village activities. Although the majority is filled by people engaged in the cleanliness and environment sector. The obstacles faced by Sukunan Tourism Village in the institutional sector are passive management and the lack of human resources who are willing to manage the tourism village. This is coupled with the pandemic condition that has not yet ended, so that they do not have an agenda for the future plans.

\section{Blue Lagoon Tourist Village}

Blue Lagoon is one of the water tourism destinations in Sleman Regency with a fairly clear river flow that is turquoise. The Blue Lagoon tourist destination was inaugurated on 22 March 2015 to coincide with the commemoration of world water day. However, the formation of the manager has been carried out since September 2014.

Over time, after going through changes and developments, in 2018 Blue Lagoon was confirmed as a tourism and cultural village that not only offers one tourist destination, but other 


\section{Jurnal Ilmu Pemerintahan: Kajian Ilmu Pemerintahan dan Politik Daerah, Vol. 6(1), April 2021 - 53}

Gerry Katon Mahendra $\mathrm{a}^{*}$, Nur Faidati ${ }^{\mathrm{b}}$

tour packages such as outbound packages, homestays, batik handicrafts, typical souvenirs, and others. The management of the Blue Lagoon tourist village is considered quite unique and independent.

From the begining, the manager has committed that the tourism village will be fully managed by tour groups with the principle of mutual cooperation, starting from tourism regulations, human resource management, merchant management and others. In addition, the Blue Lagoon tour group also rejects the presence of outside investors and refuses to merge with BUMDes in managing the tourist village.

This is done so that all forms of benefits and other joys and sorrows will later be felt and shared by group members. The results of the management of this model are finally being felt by group members and the surrounding community.

In general, the results of the management of the Blue Lagoon tourism village are felt by members / tourism workers; also managed for orphans in the neighborhood; amal Jariyah development of places of worship; social funds, youth cash funds; insurance fund; development funds, including to form and develop arts and culture in the area. This management model is indeed quite unique and rare, especially in the current era where profit and capitalism are often the main objectives.

The results of the interview with the head of the Blue Lagoon tour group explained that the original goal was to create jobs that were previously difficult to realize in the area. With the existence of these potential springs, the business was then realized. In addition, a strong commitment to protecting and managing the environment properly is also the main basis for tour groups. The philosophical view of "a little as long as it is sufficient, prosperous, and sustainable" is still held firmly today.

The institutions owned by the 10 independent tourism villages in the district are relatively different. based on the data above, it is known that there are tourist villages that have a tourism village institution that is quite very good and adaptive to the COVID-19 pandemic situation. Pentingsari Tourism Village,are examples of this category. However, there are also those whose the institutions are quite good but their adaptability is still lacking. As an examples are Pancoh Tourism Village, Pulesari Tourism Village and Kelor Tourism Village. Finally, there are also tourism villages whose institutions are not good enough and are not sufficiently adaptive to this pandemic situation. Examples of this category are Sukunan and Brayut Tourism Villages.

Tourist villages that are able to adapt are able to innovate in realizing quality tourism that pays attention to safety and health aspects through Cleanliness, Health, Safety and Environmental Sustainability (CHSE) by providing supporting facilities such as hand washing stations, provision of thermo gun, limiting visitors and just opening up tourist attractions that do not cause the potential for Covid-19 transmission. The adaptability of this innovation is an independent initiation from the management of the tourism village. Meanwhile, tourism villages that are less able to adapt tend not to take any action. These tourist villages await further direction from stakeholders such as the Sleman Regency Tourism Office and the Yogyakarta Special Region Tourism Office

\section{Conclusion}

Ideal conditions in which an independent tourism village which should be followed by a perfect institutional context does not occur in an independent tourism village in Sleman Regency, Yogyakarta Special Region. Of the 10 tourist villages, 5 of them have sufficiently good institutions and are able to adapt to a pandemic situation. Meanwhile, the other 5 are not sufficiently well-institutionalized and capable of adapting to the pandemic situation.

In order to create a tourism village that is adaptive to a pandemic situation, the Tourism

Licensed under $(\boldsymbol{M c})$ BY-NC a Creative Commons Attribution-NonCommercial 4.0 International License, 


\section{Jurnal Ilmu Pemerintahan: Kajian Ilmu Pemerintahan dan Politik Daerah, Vol. 6 (1), April 2021 - 54}

Gerry Katon Mahendra ${ }^{a^{*}}$, Nur Faidati ${ }^{b}$

Office as the stakeholder which is responsible for tourism affairs must facilitate and stimulate the emergence of innovations from existing tourism villages. The existing systems in the tourism village must be improved so that they can adapt and carry out their duties properly. With a wellfunctioning system, the sustainability of the tourist village will also be maintained.

The active participation of the community and other stakeholders in generating innovation in the management of a tourism village also determines the success of a tourist village in dealing with a pandemic. Collaborations in utilizing information technology and modifying tourist attractions that pay attention to security, health and safety aspects also in order to support the success of tourist villages in dealing with pandemics. In addition, the District Government of Sleman is also strengthening institutions to support the ability of tourist villages to adapt to pandemic situations.

Opportunities for developing research on tourist villages in the pandemic era still need to be done. Especially related to the tourism dimension in the new era of normality and quality tourism that pays attention to health and safety aspects. So far this dimension has not been explored much.

\section{References}

Arintoko, A., Ahmad, A. A., Gunawan, D. S., \& Supadi, S. (2020). Community-based tourism village development strategies: A case of Borobudur tourism village area, Indonesia. Geojournal of Tourism and Geosites, 29(2), 398-413. [Crossref]

Arsyad Sitanala. (2010). Konservasi Tanah dan Air (II). Bogor: IPB Press.

Damanik, J., \& Weber, H. F. (2006). Perencanaan ekowisata: Dari teori ke aplikasi. (Andi). Yogyakarta: Puspas UGM.

Hadiwijoyo, S. S. (2012). Perencanaan Pariwisata Pedesaan Berbasis Masyarakat (Sebuah Pendekatan Konsep). Yogyakarta: Graha Ilmu.
Huberman, M., \& Miles, M. B. (2002). The qualitative researcher's companion. Sage.

La Rocca, R. A. (2014). The role of tourism in planning the smart city. TeMA-Journal of Land Use, (3)(7), 269-284.[Crossref]

Maiti, \& Bidinger. (2017). Integrated Planning Model of Creative Industry- Based Kampung Tourism In Jayengan Surakarta, Indonesia. Journal of Chemical Information and Modeling, 53(9), 1689-1699.[Crossref]

Manaf, A., Purbasari, N., Damayanti, M., Aprilia, N., \& Astuti, W. (2018). Community-based rural tourism in inter-organizational collaboration: How does it work sustainably? Lessons learned from Nglanggeran Tourism Village, Gunungkidul Regency, Yogyakarta, Indonesia. Sustainability (Switzerland), 10(7). [Crossref]

Martshita, D. E. (2014). Strategi Pengembangan Desa Wisata Pancoh sebagai Desa Ekowisata di Kabupaten Sleman. Universitas Gadjah Mada Yogyakarta.

Milen, A. (2006). Capacity Building: Meningkatkan Kinerja Sektor Publik. Yogyakarta: Pembaharuan.

Nguyen, H. Van, Diane, L., \& Newsome, D. (2020). Kinh and ethnic tourism stakeholder participation and collaboration in tourism planning in Sapa, Vietnam. International Journal of Culture, Tourism, and Hospitality Research, 14(4), 579-597. [Crossref]

Purbasari, N., \& Manaf, A. (2018). Comparative Study on the Characteristics of CommunityBased Tourism between Pentingsari and Nglanggeran Tourism Village, Special Region Yogyakarta. E3S Web of Conferences, 31. [Crossref]

Putra, A. S., \& Fauzy, A. (2015). Pemetaan Lokasi Potensi Desa Wisata Di Kabupaten Sleman Tahun 2015. Ajie, 4(2), 123-129. [Crossref]

Riadil, I. G. (2020). Tourism Industry Crisis and its Impacts: Investigating the Indonesian

Licensed under $(\boldsymbol{c c})$ BY-No a Creative Commons Attribution-NonCommercial 4.o International License, ISSN: 2503-4685 (Print), ISSN: 2528-0724 (Online) 


\section{Jurnal Ilmu Pemerintahan: Kajian Ilmu Pemerintahan dan Politik Daerah, Vol. 6(1), April 2021 - 55 \\ Gerry Katon Mahendra ${ }^{a^{*}}$, Nur Faidati ${ }^{\mathrm{b}}$}

Tourism Employees Perspectives ' in the Pandemic of COVID-19, 4. [Crossref]

Rudwiarti, L. A., Pudianti, A., \& Vitasurya, V. R. (2017). A Comparison Study of Tangible and Intangible Culture as Commercialisation Process of Tourism Village in Yogyakarta. $E$ Journal of Tourism, 4(2), 71. [Crossref]

Sugandini, D., Effendi, M. I., ARIBOWO, A. S., \& UTAMI, Y. S. (2018). Marketing Strategy on Community Based Tourism in Special Region of Yogyakarta. Journal of Environmental Management and Tourism, 9(4), 733. [Crossref]

Sumarto, R. H., Sumartono, Muluk, K. R. K., \& Nuh, M. (2020). Penta-Helix and Quintuple-Helix in the management of tourism villages in Yogyakarta City. Australasian Accounting, Business and Finance Journal, 14(1 Special Issue), 46-57. [Crossref]

Utomo, S. J., \& Satriawan, B. (2018). Strategi Pengembangan Desa Wisata Di Kecamatan Karangploso Kabupaten Malang. Neo-Bis, 11(2), 142. [Crossref]

Vitasurya, V. R. (2016). Local Wisdom for Sustainable Development of Rural Tourism, Case on Kalibiru and Lopati Village, Province of Daerah Istimewa Yogyakarta. Procedia - Social and Behavioral Sciences, 216(October 2015), 97-108. [Crossref]
Yang, Y., Zhang, H., \& Chen, X. (2020). Coronavirus pandemic and tourism: Dynamic stochastic general equilibrium modeling of infectious disease outbreak. Annals of Tourism Research, 83(January).

\section{Author Profile}

Gerry Katon Mahendra is Lecturer at Public Administration Department of Universitas Aisyiyah, Yogyakarta. Bachelor's degree was completed from the Department of Governmental Science of the Faculty of Social and Political Sciences and Master degree was completed from Government Affairs and Administration UMY. Has a great interest in issues of public policy, public health policy and public service.

Nur Faidati is Lecturer at Public Administration Department of Universitas Aisyiyah, Yogyakarta. Bachelor's degree was completed from the Department of Governmental Science of the Faculty of Social and Political Sciences, Master degree was completed from the Department of Politics and Government of the Faculty of Physiology UGM. Has considerable research experience in Papua, and has a great interest /interest in issues of regional development, regional planning, policy and regional finance. 